\title{
人口高齢化と介護関連指標の地域特性の分析
}

\section{今井 香織*}

\section{Area Analysis of Indicators Related to Care of the Elderly}

\section{Kaori IMAI*}

As the aging of the population of Japan is estimated to accelerate in the coming three decades, problems regarding the care of the frail elderly will become serious due to, in particular, shortage of care personnel and small housing space. The aim of this study is to clarify the prefecture-based area features associated with care of the elderly and to examine the relation between these features or indicators. Analyses of 19 indicators from 47 prefectures were performed by prinicipal component analysis and cluster analysis, and they were classified into six groups called $\mathrm{A}$ to $\mathrm{F}$. The prefectures in southwest Japan and Hokkaido (group A) had low rate of aged living with their cildren, high rates of institutional beds, and many care personnel. The opposite trend was observed in those of the central and eastern Japan. Prefecture groups $\mathrm{E}$ and $\mathrm{F}$ had smaller number of institutional beds and care personnel than average; group E which included Nara, Ibaraki, Saitama prefectures in the outskirts of megalopolises was characterized by low rate of bed-ridden elderly, while group F, including such prefectures as Akita, Nigata, and Yamagata by high rate. Group C was intermediate in formal care indicators. The prefectures of megalopolises (group D) had small housing space, a small number of institutional beds and a large amount of home health aid.

Key words : care for the elderly, bed-ridden elderly, area analysis 高齢者介護, 寝たきり老人, 地域分析

\section{I はじめに}

向う四半世紀で急速に進む人口高齢化に伴っ て, 我が国では高齢者医療・福祉, なかでも寝た きりや痴呆高齢者の介護が重要な社会的問題とな ることが予測される。我が国高齢者の寝たきり有 症率は特別養護老人ホームで 4 分の 1 以上と高率
であり (厚生省 1994a)，全体的な寝たきり率は山 口県で4.7\%（岩本 1988）, 滋賀県で4.9\%（山川 1996）と報告されている。諸外国ではアメリカで, 1977年の在宅寝たきり率が 1 ～％ (Cohen 1986),ナーシングホーム入所者では約 $5 \%$ であり (入所率 $5 \%$ ) (DHHS 1986, Shick 1994), 日本 の数值が非常に高いことが指摘される. 北欧では

*北里大学医療衛生学部公衆衛生学, 現在の所属: 岡山大学医学部公衆衛生学教室.

*Department of Public Health, School of Allied Health Sciences, Kitasato University 
㾛たきり老人はほとんど存在せず，デンマークの 1986年在宅の寝たきり率は $0.1 \%$,スウェーデンの 慢性病院を含む施設全体では $4 \%$ と報じられてい る（厚生省老人保健課 1992). 高齢者の介護問題 は先進諸国共通の問題であるが，わが国における 寝たきり率の高さは, 介護をめぐる様久な問題の 所在を示している。

従来, 高齢人口の増加に伴い急増した介護負担 の多くは同居家族, あるいは入院医療によって担 われてきた。現在は新ゴールドプランによりホー ムヘルパーの増員, 特養の増床等が図られ, 老人 訪問看護制度も平成 3 年から推進されている。 かし，多様な福祉メニューが市民のニーズに従っ て手軽に日常的に利用できる水準には達していな い. 地域介護システムは, その地域の人口的, 地 理的, 社会的な特徵によって，有効な形態や人々 の選好が異なってくると考えられる. 例えば家族 形態や就業構造, 住居環境, 医療へのアクセス, また介護の受け手と提供者双方の期待と意識に よって影響される．家族の形態，あるいは施設医 療の普及形態には大きな地域差が存在し, 大都市 圈, 地方都市, 郡部, 山村等によって, その対策 も異なると考えられる。ここでは, 在宅介護に関 連すると考えられる要因に関して，地域によって 異なると考えられる特色と対策を考察するため
に，都道府県別の既存資料による地域分析を試み た.

\section{II 研究方法}

1. 分析の枠組みと資料

高齢者の介護問題は先進諸国共通の問題である が，介護需要は社会的要因と予防医学の水準によ り変化するととらえられる. 例えば介護マンパ ワーの質と量, 住宅や介護施設を含む環境のイン フラストラクチャー，またリハビリテーションを 主体とする予防医学の水準と浸透状況, 等の要因 によって介護需要は変化するし, また介護需要が それら要因に影響を与える側面も考えられる（図 1).今回はそれら介護需給の関連要因相互におけ る関連と，地域的な特徵ないし格差を把握するた めに, 既存統計資料を用いた47都道府県の地域分 析を行った。

介護関連指標として, 約 80 項目の健康指標, 社 会指標の中から，モデル（図1）に示した要因の 代理指標として，以下に示す19項目を取り上げ多 変量解析に使用した。変数の選択に当たっては, 他の変数との相関関係を検討しながら, モデル要 因に関する説明可能性を考慮して選択した。例え ば最近の都道府県別数値が入手可能な介護需要の 指標としては，国民生活基礎調査(厚生省 1994b)

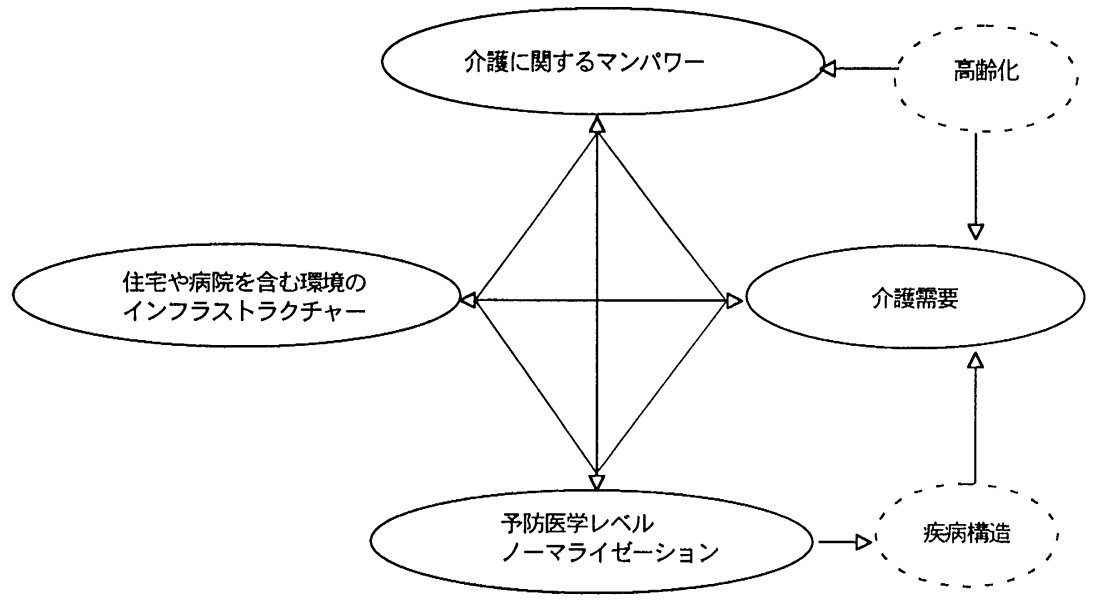

図 1 介護関連指標の模式図 
による在宅の寝たきり者, 要介護者, 1 力月以上 の就床者，また寝たきりを引き起こす各種疾患の 有病率等が考元られる。それらの中か，介護需 要指標間では相互の相関関係が低く，他の要因と の間ではできるだけ高い相関関係が得られる指標 を選んだ。また間接的に介護需要に影響する要因 として，高齢者の社会的活動性に関すると考えら れる指標一所得, 就業状況, 就業の動機等一, 健 康管理の指標一健康診断受診率等一も検討した が，モデルの項目群との関連性は弱かったので解 析には組み入れなかった。

同様にして要因別の指標を検討し，その結果以 下の19項目を選択した。

1）高齢化の指標：老年化指数（総務庁 1993）, 65歳平均余命（厚生省 1992a）

2）住宅,高齢者ケア施設等のストック：高齢者 の持家割合，高齢者一人当り住居面積（総務庁 1993), 人口対病院ベッド数（厚生省 1995a）

3）介護に関するマンパワーの指標

a）インフォーマル・マンパワー：高齢者の子 供との同居率，高齢者の単身世帯割合（総務庁 1993)

b）フォーマル・マンパワー（高齢者に対する比 率)：医療福祉従事者（病院, 保健·福祉施設, 地 域ケアの常勤換算合計), 理学療法士 (PT) 作業 療法士 (OT) (病院と保健・福祉施設の常勤換算) (厚生省 1994c,d，1995a,b)，ホームヘルパー(厚 生省 1994a）

4）在宅要介護状態の指標（65歳以上高齢者）: 在宅痹たきり有症率（厚生省 1994b）, 高血圧症, 脳卒中，慢性関節リウマチ・関節炎，骨折の通院 者率 (厚生省 1994b), 高血圧性疾患, 脳血管疾患, 骨折の入院受療率 (厚生省 1992b)，脳血管疾患死 亡率（厚生省 1995c）

\section{2. 解析方法}

保健福祉諸指標のピアソン相関係数を求めた. 次いで表 1 に示す 19 項目に関し，相関係数行列に 対する主成分分析を行った。その結果得られた固 有值が 1 以上の主成分に対応する主成分得点を用 いて，固有值による重み付けを行い，ウォード法

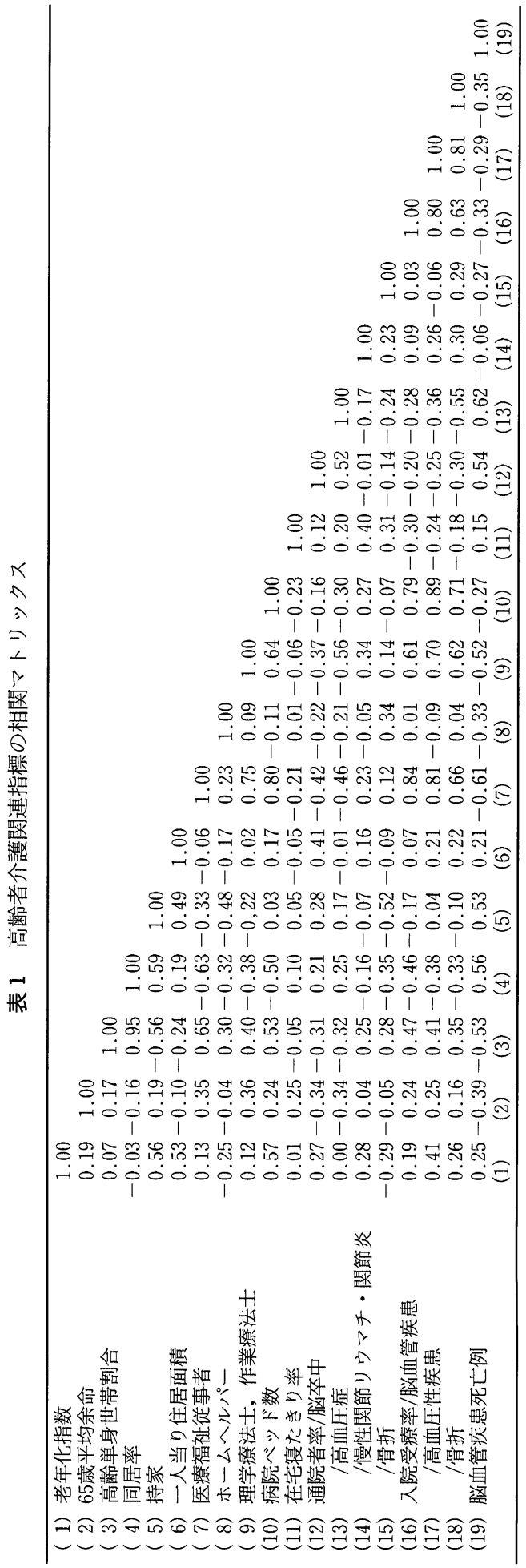


による47都道府県のクラスター分析を試みた。解 析はPC-SASv6.10を使用した。

\section{III 結 果}

\section{1. 指標間の相関係数}

1）高鈴化と他の指標との関連：表 1 に示すよ うに, 老年化指数と持家率, 住宅面積の間の相関 係数は，それぞれ0.56，0.53であった。老年化指

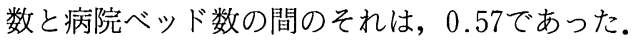

2）医療福祉従事者と他の指標との関連：医療 福祉従事者は, 同居率と $-0.63 の$ 負の相関, 高噛 単身世带割合と 0.65 , 病院ベッド数と 0.80 正の相 関を示した。同居家族の介護が困難な地域におい て施設が増床され，施設の規模によって医療福祉 従事者数が影蠁を受けている可能性が示唆され た.

3）在宅寝たきり率, 65 歳平均余命と他の指標と の関連：在宅寝たきり率との相関係数は, 慢性関
節リウマチ・関節炎の通院者率が約 0.4 , 骨折通院 者率が 0.31 , 脳血管疾患入院受療率はー0.3であっ た. 65歳平均余命に関しては, 医療福祉従事者数, $\mathrm{PT} \cdot \mathrm{OT}$ 数との間に 0.350 , 高血王症通院者率, 脸血管疾患死亡率との間に $-0.34 \sim-0.39$ の相関 が認められた。

\section{2. 主成分分析結果}

1）各成分による変動の説明と解䣋

表 2 に示す19変数を用いて主成分分析を行っ た.

第 1 主成分は，医療福祉従事者数，病院ベッド 数, 脳血管疾患, 骨折の入院受療率等と, 負で絶 対值が大きい脳血管疾患死亡率，同居率によって 代表され，施設を中心とした医療とマンパワーの 充足の指標（施設介護施策の指標）と考えられた.

第 2 主成分は, 老年化指数, 持家率, 住宅面積 と, 負で絶対值が大きいホームへルパー数が特徵 で，高齢化と都市化の指標と考えられた.

表 2 高齢者介護関連指標を用いた47都道府婓の主成分分析結果 一主成分と固有ベクトルー

\begin{tabular}{|c|c|c|c|c|c|}
\hline 嫩 & $\begin{array}{c}\text { 第 } 1 \text { 主成分 } \\
\text { 施設中心施策 } \\
\text { 指標 }\end{array}$ & $\begin{array}{l}\text { 第 } 2 \text { 主成分 } \\
\text { 高歯化 } \\
\text { 指標 }\end{array}$ & $\begin{array}{c}\text { 第 } 3 \text { 主成分 } \\
\text { 在宅要介護 } \\
\text { 指標 }\end{array}$ & $\begin{array}{c}\text { 第 } 4 \text { 主成分 } \\
\text { 平均余命 } \\
\text { 指標 } \mathrm{a}\end{array}$ & $\begin{array}{c}\text { 第 } 5 \text { 主成分 } \\
\text { 平均余命 } \\
\text { 指標 b }\end{array}$ \\
\hline 老年化指数 & 0.061 & 0.427 & 0.164 & -.091 & 0.189 \\
\hline 65藏平均余命 & 0.142 & 0.052 & 0.099 & 0.517 & 0.415 \\
\hline 高秢単身世带割合 & 0.286 & -.153 & 0.058 & -.267 & 0.337 \\
\hline 同居率 & -.276 & 0.170 & -.035 & 0.321 & -.299 \\
\hline 持家率 & -.150 & 0.423 & 0.004 & 0.262 & 0.054 \\
\hline 一人当り住居面栍 & -.020 & 0.352 & 0.170 & -.122 & -.376 \\
\hline 医療福祉従事者 & 0.363 & 0.030 & -.087 & -.024 & 0.058 \\
\hline ホームヘルパー & 0.087 & -.301 & 0.040 & -.106 & -.168 \\
\hline 理学療法士, 作業療法士 & 0.310 & 0.061 & 0.060 & 0.153 & -.105 \\
\hline 病院ベッド数/単位入口 & 0.309 & 0.267 & -.054 & -.129 & 0.113 \\
\hline 在宅将たきり率 & -.067 & -.062 & 0.621 & 0.163 & 0.235 \\
\hline 通院者率/脳卒中 & -.189 & 0.199 & 0.140 & -.416 & 0.035 \\
\hline /高血圧淀 & -.236 & 0.065 & -.090 & -.369 & 0.310 \\
\hline /慢性関節リウマチ・関節炎率 & 0.116 & 0.086 & 0.547 & -.071 & 0.008 \\
\hline /骨折 & 0.098 & -.271 & 0.393 & -.134 & -.307 \\
\hline 入院受療率/脳血管疾患 & 0.303 & 0.144 & -.183 & -.118 & 0.011 \\
\hline /高血圧性疾患 & 0.311 & 0.259 & -.073 & -.025 & -.061 \\
\hline /骨折 & 0.295 & 0.149 & 0.067 & 0.005 & -.372 \\
\hline 脳血管疾患死亡率 & -.264 & 0.231 & 0.064 & -.204 & 0.029 \\
\hline 固有値 & 6.72 & 3.44 & 1.75 & 1.63 & 1.19 \\
\hline 奇与率 & 0.354 & 0.181 & 0.092 & 0.086 & 0.063 \\
\hline 紧䅡笴与.率 & 0.354 & 0.535 & 0.627 & 0.713 & 0.775 \\
\hline
\end{tabular}




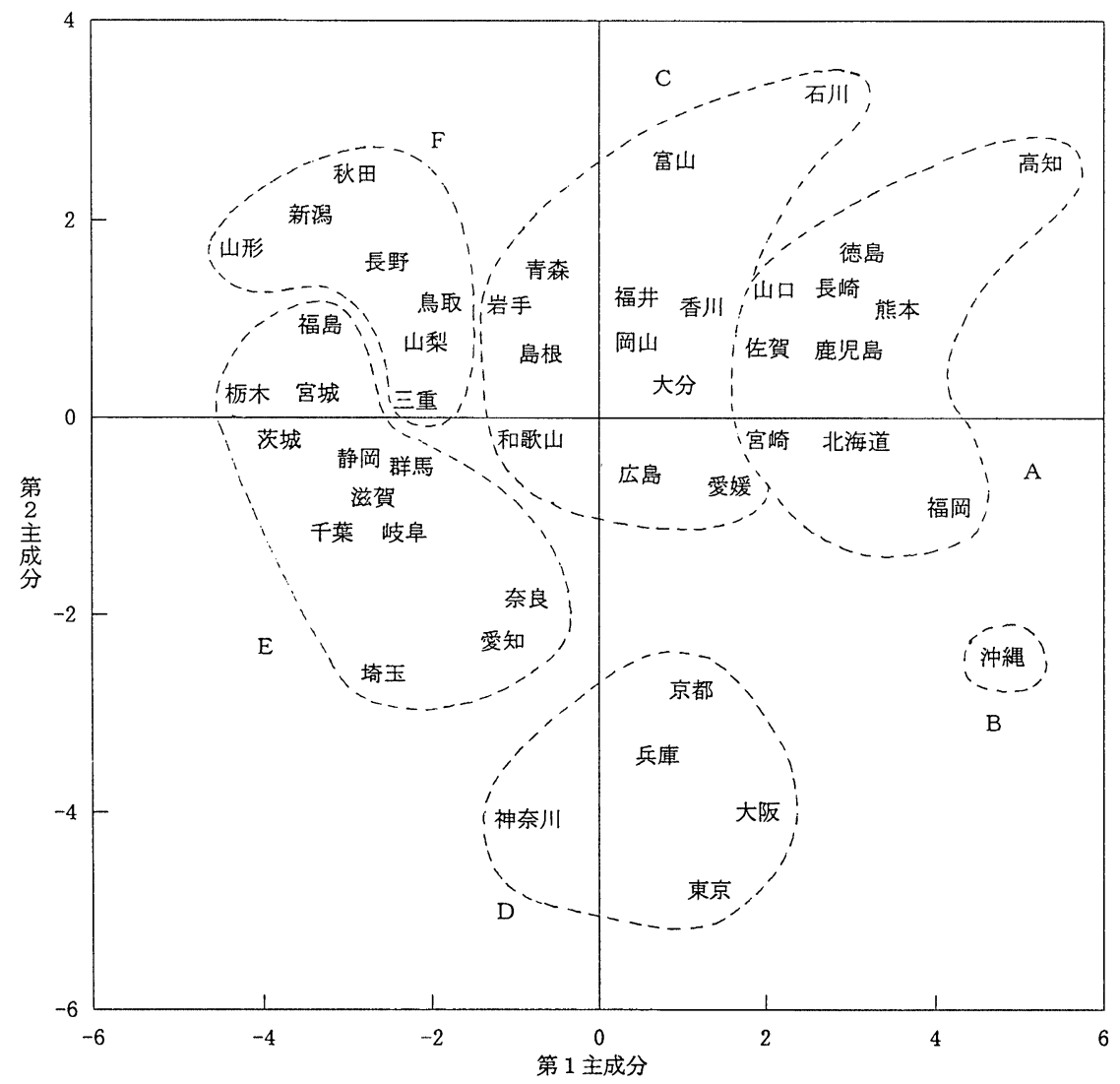

図 2 高齢者の介護関連指標, 都道府県の主成分スコアーとクラスタリング (点線内)

第 3 主成分は, 在宅寝たきり率, 慢性関節りウ マチ・関節炎と骨折の通院者率に代表され，在宅 の要介護指標と解釈された。

第 4 主成分は，65歳平均余命と，逆符号の脳血 管疾患および高血圧症の通院者率に代表される平 均余命の関連指標と考えられた。第 5 主成分も 65 歳平均余命と，逆符号の骨折入院受療率，骨折通 院者率が特徵の平均余命の関連指標と考元られ た。

固有值は第 1 主成分が 6.7 , 第 2 主成分が 3.4 , 以下順に $1.7,1.6,1.2 て ゙$, 第 5 主成分までの累積 寄与率は $78.5 \%$ を示した。

3. クラスター分析結果

主成分分析で得られた主成分のうち，固有值が 1 以上の第 5 主成分までを用いてウォード法によ
るクラスター分析を行った結果， $\mathrm{A} \sim \mathrm{F}$ 群の 6 ク ラスターが得られた(図 2 )。各クラスター毎の主 要な指標の平均値を表 3 に示した。

クラスターA は，施設中心施策の第 1 主成分ス コアーが大きい群であり，第 2 主成分で表される 高齢化は平均するとやや進んでいると考えられ た。 九州の大部分（鹿児島, 宮崎, 熊本, 長崎, 佐賀，福岡）と，高知，徳島，山口ょりなり，北 海道もここに属した。同居率が平均 $49 \%$ と，大都 市群（D 群）と並ぶ低さを示すことが特徵と考え られた。

沖縄は単独でクラスターB を形成した。施設中 心施策の指標が大きく, 高齢化は最もゆるやかで, 高齢者一人当たりの住宅面積が $24.6 \mathrm{~m}^{2}$ と最も挟 い值を示した。 
表 3 都道府県のクラスター別, 指標の平均值

\begin{tabular}{|c|c|c|c|c|c|c|c|}
\hline 指 & 標 & A群 & B群 & C 群 & $\mathrm{D}$ 群 & E群 & F群 \\
\hline 老年化指標 & & 78.5 & 40.4 & 80.8 & 63.4 & 62.0 & 83.4 \\
\hline 同居率 & $\%$ & 49.1 & 55.0 & 59.8 & 49.0 & 67.7 & 67.7 \\
\hline 一人当り住居面積 & $\mathrm{m}^{2}$ & 32.9 & 24.6 & 36.1 & 30.0 & 31.8 & 35.5 \\
\hline 医療福祉従事者 & 人/65以上干対 & 54.3 & 62.7 & 43.4 & 44.5 & 34.5 & 34.0 \\
\hline ホームヘルパー & /65以上十万対 & 356.4 & 365.9 & 298.5 & 622.8 & 305.4 & 248.1 \\
\hline 病院ベッド数 & /人口十万対 & 2,022 & 1,572 & 1,607 & 1,230 & 1,172 & 1,273 \\
\hline 在宅将たきり率 & $\%$ & 14.1 & 27.1 & 18.9 & 19.1 & 16.7 & 21.5 \\
\hline 通院者率/骨折 & /65以上千対 & 7.8 & 7.9 & 8.8 & 12.5 & 7.3 & 7.5 \\
\hline
\end{tabular}

C 群は施設中心施策指標が中位の地域群より なった. C群の中でも石川, 富山, 青森, 岩手, 福 井は, 大分, 愛媛, 香川, 島根, 広島, 岡山, 和 歌山に比較して, 高齿化が進み, 高い同居率を示 した。

$\mathrm{D}$ 群は東京, 神奈川, 京都, 大阪, 兵庫の大都 市圈群であった。老年化指数は平均 63.4 と低く, 同居率，住宅面積の值も低值を示した。大阪を除 いて，ホームへルパー数が突出して多いことが特 徵であった。

$\mathrm{E}$ 群と $\mathrm{F}$ 群は両者で大きなクラスターを形成 した. 病院ベッド数, 福祉ベッド数, 医療福祉従 事者数が少なく, 同居率が高い点が特徴であった。 $\mathrm{E}$ 群には奈良, 滋賀, 愛知, 静岡, 埼玉, 千葉, 群 馬, 茨城, 岐阜, 栃木, 宮城, 福島が含まれ, 大 都市近郊あるいは中核都市圈と考えられた。老年 人口割合と老年化指数それぞれの平均值は 12 と 62 を示した。 F 群は秋田, 新潟, 山形, 長野, 鳥取, 山梨, 三重が含まれた. F 群の老年人口割合, 老年 化指数の平均值はそれぞれ 15,83 と高く，5群中 で最も高齢化が進展しており，在宅寝たきり率も 21.5 と高い数值を示した.

第 3 主成分の在宅要介護指標に関しては，上位 13地域はすべて A 群あるいは $\mathrm{E}$ 群に属していた。

\section{IV 考察}

介護はサービス提供者によって, 組織的な フォーマル・ケアと，家族によるインフォーマル・ ケアに大別される. 同居家族による介護は情緒的 サポートと，24時間対応可能というきめの細かさ
が利点であるが，介護者への負担が大きく，また 近親者ゆえの依存心を招く欠点をも有している. 一方組織的な介護は, 専門的技術を背景とした教 育的・予防的対応が利点と考えられる，高秢者を めぐる家庭環境は急速に変化しているが，現状で はわが国は $59.6 \%$ と高い同居率を示し，寝たきり 老人の在宅介護は 9 割以上が同居家族によって担 われている。

主成分分析の結果得られた第 1 主成分は, 病院 ベッド数の多さ，医療福祉従事者の多さ，低い同 居率に代表され, 家族介護と代替的な施設を中心 としたフォーマル・ケアの優勢を表す指標と解釈 される。この数值は総じて西日本が高く, 東日本 では低い，同居率は大都市と九州，四国，中国で 低く，東北，北陸，中部で高い東高西低の傾向が あり, 医療福祉従事者あるいは福祉従事者は逆に 西高東低の傾向が見られる．また，同居率の高さ はマンパワー, 病院ベッド数と中程度の負の相関 関係を示し，同居率の高さと病院医療の充実の間 の代替的な関係が示唆される。第 2 主成分は高齢 化指標と考えられ, 住居面積も関連しており, 都 市化の指標ともみなせる。

主成分のクラスター分析により得られた $\mathrm{A}$ 群 は，平均的にはやや高齢化した「入所施設増床型」 で高知, 福岡等の九州四国地域と北海道が含まれ る. B 群は高齢化の度合いが低く,「入所施設増床 型」の沖縄である．F 群は「高齢化, 家族介護優勢 型」で山形, 新潟, 秋田, 長野, 鳥取, 山梨, 三 重が該当する. E 型は「大都市近郊, 家族介護優勢 型」で主に大都市近郊および中核都市により構成 
される. $\mathrm{D}$ 群は「大都市型」で東京, 神奈川，大 阪, 兵庫, 京都よりなる。C 群はやや高齢化した「介 護施策中間型」地域であると言える。

家族の形態に関しては清水（1986）によると， 西南日本地域では人口高歯化が進展しかつ高齢核 家族世帯数が進展している「鹿児島県農村的」な 家族形態の特徵が多く見られ, 東北日本では人口 高齢化が進展しているにもかかわらず，高齢核家 族世帯率が進展していない「岩手県農村的」な家 族形態が観察される。東北日本農村の拡大志向型 家族を支えている価值体系は, 親子関係を常に優 先させる体系であり, 西南日本の縮小志向型家族 を支えているのは夫婦関係を親子関係よりも優先 させる価値体系であると指摘されている（蒲生 1979).

「入所施設増床型」の $\mathrm{A}$ 群は, 九州四国の 8 県に 北海道と山口が加わっている，同居率は平均 $49 \%$ と最低で, 医療福祉従事者は54人（高齢者千対） と最高を示し，この群の在宅寝たきり率は 14.4 と 最も低い. 縮小志向家族の形態が最も強い $\mathrm{A}$ 群で は高齢者核家族世帯, 単身世帯率が高く, 福祉施 設ベッド数, 病院ベッド数が多いことが特徵であ る. 在宅寝たきり率と病院ベッド数は弱い負の関 係を示すことから, 病院入院による福祉機能代替 の可能性が指摘される. 対策として福祎施設機能 の充実と, 高齢者の自立をサポートする在宅介護 システムの充実が求められる.

沖縄はいくつかの特徴的側面を有しているた め, 単独で B 群を成している. 高齢化の度合いは 最低で, 平均寿命は高く, 脳血管疾患死亡率は最 も低いが在宅寝たきり率は高い. 病院, 福祉施設 とも単位高齢者当たりのベッド数は多いが，ホー ムヘルパー数が少ない.また，高齢者一人当たり の住宅面積は全国最低であるが，この点に関して は第二次世界大戦の影響以外に, 持家が少なく借 家が多いこと，伝統的な家族同居による扶養形態 が強いこと等による住宅問題が指摘される.

「介護施策中間型」の $\mathrm{C}$ 群は, ベッド数とマンパ ワー数が中間的数值を示して扔り，同居率に関し ては拡大家族志向の東日本地域と, 縮小家族志向
の西日本地域の 2 つのグループが含まれている. 後者に該当する愛媛, 香川, 広島, 岡山の寝たき り率は高値である。

$\mathrm{D}$ 群の大都市型の特徵は, 同居率と住宅面積が 低值であること，大阪以外はホームヘルパー数が 抜きん出て多く, 福祉施設ベッド数が著しく少な いことである，また，骨折の通院治療率が高い. 大都市では同居家族による介護は困難であり，住 環境は狭く危険が多い。安全で快適な住居あるい は居住型施設の供給と街作りが望まれる。

同居率が高く，施設指標とフォーマル・マンパ ワー指標が低い地域を,「家族介護優勢型」と仮称 する．この地域は高齢化が進んで在宅要介護指標 の高い F 群と, 大都市近郊で高齢化の程度は低 く, 在宅要介護指標は比較的低い $\mathrm{E}$ 群に分かれ た.「大都市近郊, 家族介護優勢型」の $\mathrm{E}$ 群は近畿 以東の大都市近郊地域であり, 多くは低い德たき り率を示している。施設およびマンパワーの低率 さにもかかわらず $\mathrm{E}$ 群地域の要介護指標が相対 的に良好であるのは, 高齢化が進展してないこと， 大都市近郊で医療へのアクセスは良好である等の 条件が影響している可能性が考えられる。しかし E群においても将来の高齢化は免れず, 総じて貧 弱である福祉施設とフォーマル・マンパワーの充 実施設は必須である。

「高齢化, 家族介護優勢型」の $\mathrm{F}$ 群は, 同居率に 関しては $\mathrm{E}$ 群と同值であるが, 老年化指数が 83.4 と 5 群中最も高い. ホームヘルパー数と保健福祉 従事者数は最低を示している.寝たきり率は $\mathrm{E}$ 群 16.7に対し，21.5と高率である. 高齢化の進展は， 介護対象者と介護提供者双方の高齢化につなが る. 高齢化が進行し, かつ施設数とマンパワー率 が低值の場合, 在宅要介護指標の悪化を招くこと が示唆される. 高齢化の進展によって介護者の高 齢化も進み, 同一世帯内に複数の虚弱者や要介護 者が存在する世帯が増加し, 同居家族へのサポー トが緊急性を増す. 高齢化進行地域における同居 家族ケアへの偏向は, 介護提供者, 要介護者双方 の健康を阻害する要因となり得る。

都道府県別にみた老人保健・福祉事業の分類は 
佐藤（1995）によっても試みられている.クラス ター分析を用いた高柃化率, 医療費, 保健福祉サ一 ビスの利用状況による分析結果は,「在宅保健福祉 充実型」，「施設充実典型型」と「機能訓練突出型」 の 3 群からなる I 群クラスターと,「施設後進典型 型」,「在宅保健福祉後進型」,「ショートステイ偏 重型」のII群クラスターとして分類されている.

II群は I 群に比べ，医療費，特別養護老人ホーム の定員率，ホームヘルパー，デイサービスの年間 利用日数において低値を示している. 本稿との比 較では，I 群クラスターには愛媛を除く本稿の $\mathrm{A}, \mathrm{B}, \mathrm{C}$ 群が相当し，II群には秋田と三重を除く $\mathrm{E} ， \mathrm{~F}$ 群都府県が該当している，ただ，「在宅保健 福祉充実型」，「施設充実典型型」といっても国内 での相対的位置に過ぎず，実態は「充実」と言え るものではない．例えばホームへルプサービスの 担い手であるホームヘルパー数は全国 9 万 2 千人 で，新ゴールドプラン目標值は 17 万人であるが， ホームヘルプを受けている高齢者の割合は，デン

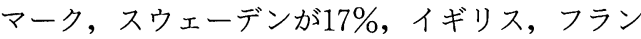
スが $7 \sim 8 \%$ に対して，日本は $1 \%$ 以下にとど まっている(OECD 1994)。また，アメリカの地域 において，縁者のみで介護している割合は約 3 割 であり，緑者と組織的なへルプ両者に依っている 割合は約 3 割にのぼっている (Stone 1987)。また 施設に関しては，福祉の不足を病院病床により代 替する現状が見られ，ベッド当たりスタッフ数は 国際的に比較して少ない．施設における高い寝た きり有症率自体が，介護需給のミスマッチにより 引き起こされた問題と考えられる。

日本全域で進行している高齢化と，鹿児島を中 心とする西南日本地域で特に進んでいる高齢者の 核家族化は，世帯内部での介護の調達を困難にす る.また近年進んでいる女性の労働力化に関して, 就労女性の意識調査（東京都立労働研究所 1991） によると，女性の稼働所得が増えるにつれ介護の 機会費用が上昇し，フォーマル・ケアへの選好と 需要が高まることが示唆される．介護の外部化は 必須であり，それぞれの地域特性に根ざしたケ ア・システム構築が重要性を増すと考えられる。

\section{V まとめ}

高齢化と在宅介護の関連指標に基づき都道府県 を分類したＡ～群はやや高齢化した「入所施設増 床型」で，九州四国地域が中心で北海道が加わっ ている，同居率が最も低く，入所型施設への需要 が大きいと考えられる，在宅寝たきり率は最も低 い. B 群は「入所施設増床型」の沖縄で，住宅に 問題がある.寝たきり率は高い.C 群はやや高秢化 した「介護施策中間型」地域である。D 群は「大 都市型」で，福祉施設対策は遅れているが，ホー ムヘルパー数の多さが突出している.E群は「大都 市近郊，家族介護優勢型」で，高歯化は緩やかで 同居率が高い，病院ベッド数と医療福祉従事者数 は少ないが，寝たきり率は比較的低い，F 群は「高

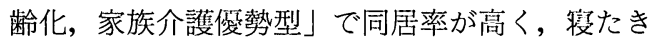
り率が高率である。

謝辞：研究の遂行に関しご助言いただきました門脇 武博教授，福富和夫先生，ならびに地域分析の必要性 に関して示唆をいただき，人口学的見地からご指導を いただきました中央大学経済学研究科教授の大淵 宽 先生に深謝申し上げます。

\section{文献}

蒲生正夫 (1979)：日本のイエとムラ，大林太良 監， 世界の民族, 東アジア，13卷，22-43，平凡社.

Cohen, M.A., Tell, E.J. \& Wallack, S.S. (1986) : Client-related risk factors of nursing home entry among elderly adults, J. Gerontol, 41(6), 785-792 岩本 晋, 青木龍哉, 恵上法男, 芳原達也(1988)：高 歯者の入院実態，病院機能と在院期間の関係につい て, 公衆衛生, 35(3), 151-158

厚生省大臣官房老人保健福祉部老人保健課（1992）: 寝たきりゼロをめざして，寝たきり老人の現状分析 並びに諸外国との比較に関する研究，14，中央法規 出版 (東京)

厚生省大臣官房統計情報部編

(1992a）：平成 2 年都道府県別生命表，厚生統計協 会

(1992b)：平成 2 年患者調查, 厚生統計協会 (東京)

(1994a）：平成 5 年社会福祉行政業務報告，愿生統 計協会

（1994b）：平成 4 年国民生活基礎調査，愿生統計協 会 
(1994c)：平成 4 年老人保健施設実態調査・老人保 健施設報告，厚生統計協会

(1994d)：平成 5 年社会福祉施設調查報告, 厚生統 計協会

(1995a)：平成 5 年医療施設調査, 厚生統計協会

(1995b)：平成 6 年衛生行政業務報告, 厚生統計協 会

(1995c)：平成 5 年人口動態統計, 厚生統計協会

Organisation for Fconomic Co-operation and Development (OECD) (1994) : Caring for Frail Elderly People, 41, OECD (Paris)

佐藤秀紀, 中嶋和夫, 安西将也 (1995): クラスター 分析による都道府県別にみた老人保健・福祉事業の 累計化，厚生の指標，42(10), 18-24

Shick, F.L. \& Shick, R. (edited) (1994) : Staistical Handbook on Aging Americand 1994, 152, Orix Press (Arizona)

清水浩昭(1986)：人口と家族の社会学, 165-253, 犀 書房 (東京)
総務庁統計局（1993）：平成 2 年国勢調查解説シリー ズ No. 2 都道府県の人口，総務庁統計局

Stone, R., Cafferaata, G.L. \& Sangl, J. (1987) : Caregivers of the frail elderly. A national profile, The Gerontologist, 27(5), 616-626

東京都立労働研究所 (1991)：中高年婦人の就労と介 護問題に関する調査, 1-78, 東京都立労働研究所(東 京)

U.S. Department of Health and Human Services (DHHS) (1987): Public Health Service, National Center for Health Statistics, 1987. Health Statistics on Older Persons, Inited States 1986, 71-72, US Government Printing Office (Washington, D.C.)

山川正信, 上島弘嗣, 岡山 明, 喜多義邦, 他(1994): 訪問悉皆調査による在宅高齢者の ADL (日常生活動 作能力)の実態, 公毷衛生, 41(10), 987-996

(受稿 1996.4.15; 受理 1996.11.15) 